\title{
ПОЛИМОРФНЫЕ STR МАРКЕРЫ КАК ИНСТРУМЕНТ ПОПУЛЯЦИОННО-ГЕНЕТИЧЕСКИХ ИССЛЕДОВАНИЙ МЕДОНОСНЫХ ПЧЕЛ Apis mellifera L.*
} (обзор)

\author{
О.Ю. ФОМЕНКО ${ }^{\circ}$, М.С. ФОРНАРА, А.В. ДОЦЕВ
}

Медоносные пчелы (Apis mellifera L.) жизненно важны для существования многих сельскохозяйственных культур (рапс, подсолнечник, бобовые), а также для сохранения естественного биоразнообразия растений. Актуальность всестороннего изучения биологии медоносной пчелы возрастает с каждым годом. В первую очередь это вызвано намечающимися во всем мире (включая Российскую Федерацию) негативными процессами в популяциях медоносных пчел. Исторически на территории Европы и Африки обитал только один представитель рода Apis - медоносная пчела Apis mellifera, образовавший в процессе эволюции значительное число рас (подвидов), способных свободно скрещиваться друг с другом. В дальнейшем вид Apis mellifera был расселен человечеством по всему миру. В настоящее время наиболее опасна потеря уникальных генофондов аборигенных подвидов пчел и их чистопородности вследствие бесконтрольной гибридизации (P. de la Rúa c соавт., 2009). При этом важное значение в сохранении естественного генетического разнообразия отечественных пород медоносной пчелы приобретает изучение генетической структуры и эволюционных взаимосвязей популяций $A$. mellifera на территории Российской Федерации, определение чистопородности имеющегося и импортируемого в страну племенного поголовья пчел, генетическая паспортизация пчел, выявление геномных ассоциаций с хозяйственно полезными признаками (яйценоскость маток, летная деятельность пчел, медовая и восковая продуктивность, устойчивость к паразитам, зимостойкость, компоненты маточного молочка, пчелиного яда), а также разработка методов оценки племенной ценности медоносных пчел. Необходимым условием сохранения и поддержания полиморфизма как компонента устойчивости популяции становится определение параметров групповых характеристик популяций и линий (Н.И. Кривцов с соавт., 2011). Также особую значимость при оценке состояния генофонда пород пчел и оптимизации подбора исходного материла для селекции приобретает изучение генетической структуры популяций племенных хозяйств и выяснение эволюционных отношений между географически изолированными популяциями. В представленном обзоре рассматриваются общие вопросы структурной организации микросателлитных маркеров (STR, short tandem repeats), основные модели их эволюции (Н. Fan с соавт., 2007), а также возможные механизмы возникновения микросателлитных последовательностей в геномах эукариот (А.В. Омельченко, 2013). Микросателлиты представлены короткими тандемными повторами (размер мономерного звена от 2 до 6 п.н.), дисперсно расположенными по всей ядерной ДНК (W.S. Sheppard с соавт., 2000). Они могут быть локализованы как в некодирующих участках (в том числе в регуляторных областях), так и в кодирующих областях генома (I. López-Flores c coaвт., 2012). Считается, что одним из ключевых процессов, приводящих к возникновению и способствующих экспансии микросателлитов, является образование разнообразных неканонических структур ДНК, благоприятствующих проскальзыванию вилок репликации (R.D. Wells, 1996). Микросателлитные локусы представляют собой очень удобный инструмент для анализа генетической структуры популяций, оценки степени инбридинга и гетерозиготности, вычисления коэффициентов генетического родства и определения степени интрогрессии. В обзоре описано применение STR маркеров для выявления эволюционной истории медоносной пчелы. Обобщены основные работы по изучению генетической структуры популяций Apis mellifera различных подвидов, встречающихся на территории Европы, Азии, Америки и Африки. Отдельно уделено внимание изучению популяций отечественных пород и породных типов медоносных пчел. STR маркеры продолжают оставаться чрезвычайно мощным средством геномного картирования, определения достоверности происхождения, популяционно-генетических и эволюционных исследований благодаря значительному числу характерных аллелей, высокой частоте происходящих мутационных событий и кодоминантному типу наследования.

Ключевые слова: медоносная пчела, микросателлитные маркеры, STR маркеры, эволюция, популяционная генетика, генофонд, интрогрессия.

Медоносные пчелы (Apis mellifera L., Hymenoptera: Apidae) - основные насекомые-опылители на планете, жизненно важные для существования многих сельскохозяйственных культур (рапс, подсолнечник, бобовые),

* Работа проводилась в рамках выполнения государственного задания по теме № 0445-2019-0024.

1090 
а также для сохранения естественного биоразнообразия растений. С 1961 по 2007 год зависимость сельского хозяйства от опылителей в развитых и развивающихся странах выросла соответственно на 50 и $62 \%$ (1).

Актуальность всестороннего изучения биологии медоносной пчелы возрастает с каждым годом, что вызвано наметившимися негативными процессами, протекающими в популяциях этого насекомого как в Российской Федерации, так и во всем мире. Во-первых, растет давление биотических и абиотических факторов окружающей среды на пчелиные семьи, вследствие чего снижается их численность. Например, в Европе за 20 лет число пчелиных семей снизилось на 16 \% (2). В США ежегодные потери пчелиных семей приближаются к 50 \% (3). Массовая гибель пчелиных семей, по мнению многих исследователей, в краткосрочной перспективе может привести к непоправимым последствиям, вплоть до полного исчезновения пчеловодства. Во-вторых, ввоз и воспроизведение подвидов Apis mellifera, не обоснованные научно, бессистемные и бесконтрольные, ведут к массовой гибридизации пчел и потере чистопородности (4). С высокой долей достоверности эти процессы связаны с массовым коллапсом пчелиных семей.

Пчелы гибридных линий обладают меньшей устойчивостью к неблагоприятным факторам окружающей среды, таким как абиотические стрессфакторы $(5,6)$ и воздействие пестицидов $(7,8)$, и характеризуются пониженным иммунитетом (9-11), что повышает их восприимчивость к паразитам $(12,13)$ и патогенам $(14,15)$. Результатом межпородной гибридизации становится снижение адаптации гибридных пчелиных семей к меняющимся условиям окружающей среды, что неизбежно приводит к возрастающей гибели пчел. Одним из ключевых факторов, обусловливающих гибель пчелосемей в зимний период на территории Европы, признаются эктопаразитические клещи Varroa destructor, вызывающие варрооз (16), и микроспоридии Nosema ceranae, становящиеся причиной нозематоза типа С (17).

При гибридизации и потере чистопородности происходит утрата генофондов аборигенных подвидов пчел (18-20). В настоящее время темная лесная пчела Apis mellifera mellifera L., один из уникальных подвидов медоносной пчелы, признан исчезающим на территории Европы (21). Таким образом, вопросы сохранения генофонда и аборигенных популяций медоносной пчелы A. mellifera приобретают планетарное значение.

Из-за пугающих масштабов межпородной гибридизации важной задачей российского пчеловодства становится сохранение генофондов популяций отечественных пород и подвидов пчел. Для сохранения аборигенных популяций медоносной пчелы у России имеется ряд уникальных возможностей $(18,22,23)$. Среднерусская порода медоносной пчелы A. mellifera mellifera, наиболее адаптированная к продолжительной зиме с низкими температурами и устойчивая к ряду заболеваний, представляет значительный интерес и рекомендована к разведению на большей части территории страны (24). Для восстановления генофонда среднерусской породы могут быть использованы две сохранившиеся в Красноярском крае и Башкортостане крупные популяции среднерусской пчелы - енисейская и бурзянская.

Целью настоящего обзора стало рассмотрение некоторых аспектов молекулярной природы микросателлитных локусов и механизмов их эволюции, а также ретроспективный анализ использования микросателлитных маркеров в популяционной генетике пчел.

Эволюция медоносной пчелы $A$. mellifera в ее естественном ареале происходила в различных климатических зонах, что на территории Старого Света привело к подразделению вида на 30 подвидов (по некоторым данным, на 31), из которых к существованию в климатических условиях 
Северной Европы приспособлен только A. m. mellifera (25). При этом Европа была эволюционной колыбелью медоносной пчелы, что выразилось в формировании 10 подвидов, которые представляют собой существенную часть общего генетического разнообразия $A$. mellifera $(26,27)$.

Подвиды медоносной пчелы подразделяются как минимум на пять эволюционных линий - А (Африка), М (Западная Европа), С (Восточная Европа), О (Ближний Восток) и Y (Северо-Восточная Африка) (28). Европейские подвиды группируются в две эволюционные линии - М и С. Последняя в настоящее время включает большое число подвидов, в том числе два подвида, которые широко используются в мировом промышленном пчеловодстве, - итальянскую медоносную пчелу A. mellifera ligustica и карнику A. mellifera carnica.

В ареале своего естественного распространения европейские медоносные пчелы подвергаются воздействию факторов как не связанных с пчеловодческой деятельностью (применение агрохимии, разрушение и фрагментирование мест обитания), так и имеющих к ней непосредственное отношение (завоз паразитов и патогенов, целенаправленная интродукция инородных маток) (29). Из всех европейских подвидов медоносной пчелы подвид $A$. m. mellifera наиболее подвержен давлению указанных факторов, среди которых важнейшую роль играет интрогрессия $(21,30,31)$. Растущее понимание важности аборигенных подвидов как ценного источника генетического материала для устойчивого развития пчеловодства привело к созданию в Северной Европе защищенных территорий для сохранения генетической целостности темной европейской медоносной пчелы (30-33).

Ранее считалось, что темная лесная пчела не находится под угрозой исчезновения, поскольку ее демография поддерживается деятельностью пчеловодов. Однако недавно было показано, что человеческая активность не способна компенсировать утрату биоразнообразия медоносных пчел, и охранный статус $A$. $m$. mellifera на территории Европы требует пересмотра (34). За последние 200 лет ареал этого подвида в Евразии существенно сузился вследствие интенсивного сведения лесных массивов, интродукции на привычные места обитания различных южных подвидов и сопутствующего ей широкого распространения новых инвазионных и инфекционных заболеваний (варроатоз, нозематоз типа С, аскосфероз и др.). В некоторых европейских странах генофонд темной лесной пчелы A. m. mellifera признан утраченным. Нарушение непрерывности ареала аборигенного подвида было вызвано интрогрессией южных подвидов в Западной и Северной Европе, что связано с предпочтительным разведением пчел эволюционной ветви С. Например, на территории Европы A. m. mellifera частично, а в ряде случаев и полностью вытеснена некоренными пчелами, например A. m. ligustica в Северной Европе (21) и $A$. m. carnica в Германии $(35,36)$. На большей части российского ареала $A$. m. mellifera заменен подвидами $A$. m. carpatica и $A . m$. caucasica (37). В ближайшем будущем генофонд $A$. $m$. mellifera может быть безвозвратно утерян вследствие активной интрогрессии генов иных эволюционных линий и общего снижения эффективной численности подвида. Если не будет реализована стратегия сохранения этого подвида, то коллапс пчелиных семей, семейная интрогрессия и популяционные сдвиги приведут к вымиранию темной лесной пчелы, что неоднократно случалось с другими видами (38).

Важнейшее значение в сохранении естественного генетического разнообразия отечественных пород медоносной пчелы приобретает изучение генетической структуры и эволюционных взаимосвязей популяций $\mathrm{A}$. mellifera на территории Российской Федерации, определение чистопородности 
имеющегося и импортируемого в страну племенного поголовья пчел, генетическая паспортизация, выявление геномных ассоциаций с хозяйственно полезными признаками (в частности, с яйценоскостью маток, летной деятельностью пчел, медовой и восковой продуктивностью, устойчивостью к паразитам, зимостойкостью, компонентами маточного молочка, пчелиного яда), а также разработка методов оценки племенной ценности медоносных пчел и практическое использование геномной селекции A. mellifera.

При оценке состояния породного генофонда пчел и оптимизации подбора исходного материала для селекции обязательным становится изучение генетической структуры популяций племенных хозяйств и выявление эволюционных отношений между географически изолированными популяциями. Для сохранения генофонда требуется проведение генетической паспортизации пчел - получения с помощью морфологических и/или молекулярных маркеров их индивидуальных и/или групповых генетически детерминированных параметров. Для сохранения и поддержания полиморфизма как компонента устойчивости популяции необходимо определять параметры и групповые характеристики популяций и линий (39).

Принято считать, что для популяций как эусоциальных, так и одиночных представителей отряда Hymenoptera характерна крайне низкая степень полиморфизма аллозимных локусов (40-43). В популяциях, отличающихся относительно низкой аллозимной изменчивостью, таких как большинство популяций медоносных пчел, проведение популяционно-генетических и социобиологических анализов затруднено (44). При поиске полиморфизмов, адекватных для такого рода исследований, большое внимание было обращено на ДНК маркеры, особенно связанные с изменчивостью длины - минисателлиты (ДНК-фингерпринт, VNTR, variable number tandem repeat) (45) и микросателлиты (STR, short tandem repeats) (46). Минисателлиты - это тандемные повторы длиной 15 п.н. и больше, расположенные обычно в межгенных участках. Микросателлиты состоят из очень коротких тандемных повторов с размером мономерного звена от 2 до 6 п.н., дисперсно расположенных по всему ядерному геному (47). Микросателлиты могут быть локализованы как в некодирующих регионах (в том числе в регуляторных областях), так и в кодирующих (48). При этом микросателлиты, расположенные внутри кодирующих белки участков, ожидаемо являются тринуклеотидными повторами, так как в противном случае рамка считывания ДНК нарушается. Протяженность кластеров микросателлитов составляет в среднем от 20 до 60 п.н. (исключение - ряд наследственных заболеваний человека, при которых наблюдается экспансия триплетных повторов).

Одними из наиболее актуальных вопросов биохимии и молекулярной биологии нуклеиновых кислот остаются молекулярные механизмы и характеристика процессов нестабильности генома. Фактором подобного рода нестабильности выступают, в частности, микросателлитные последовательности ДНК. Благодаря высокой скорости мутационных процессов в микросателитных участках (от $10^{-2}$ до $10^{-5}$ событий на локус на поколение), зависящей от типа микросателлита (49), в них достаточно быстро накапливаются популяционно-специфические мутации, что позволяет использовать информацию об изменчивости микросателлитных локусов при анализе структуры популяций (50). Исследования микросателлитных участков ДНК показали, что происходящие в них изменения весьма разнообразны и зависят от типов повторов, аллелей, видовой и половой принадлежности живых организмов, а также возраста особей (51).

Существует несколько моделей, объясняющих изменчивость микросателлитных локусов (52-55). Большинство из них укладывается в так 
называемую модель «шаг за шагом» (stepwise mutational model, SMM), в рамках которой изменения длины микросателлитных локусов происходят последовательно за счет увеличения или уменьшения длины повтора на один нуклеотид. Один из основных механизмов, приводящих к возникновению и способствующих экспансии микросателлитов, - проскальзывание вилок репликации при образовании тироидов (56). Наличие комплементарных взаимодействий между ДНК/ДНК дуплексами нуклеотидов в участках молекулы ДНК, фланкирующих микросателлитный локус, обеспечивает устойчивость этих структур $(57,58)$. Таким образом, формирование шпильки и петли, а затем проскальзывание цепей ДНК в процессе репликации - ключевые положения мутационной модели «шаг за шагом» (59).

Благодаря компьютерному моделированию вторичной структуры молекул ДНК удалось установить связь между числом мономерных звеньев в микросателлитных кластерах и способностью молекул ДНК образовывать неканонические вторичные структуры. Показано, что возникновение неканонических структур связано также с видами единичных нуклеотидных замен в микросателлитных звеньях и типами микросателлитных кластеров (60-62). Имеются данные, свидетельствующие о полярности мутаций внутри микросателлитных ДНК (63) и повышенной частоте однонуклеотидных замен во фланкирующих микросателлиты областях ДНК (64). На примере динуклеотидных микросателлитов беспозвоночных было показано, что частота мутаций во фланкирующих участках может превышать частоту мутаций в самом микросателлитном кластере (65).

Считается, что тандемные повторы в целом и микросателлитные последовательности в частности играют важную роль в функционировании генома на субклеточном, биохимическом и молекулярном уровнях (66). В настоящее время к наиболее изученным относятся микросателлиты человека, ряда животных и растений $(67,68)$. При этом наиболее интересны широко представленные в геноме эукариот динуклеотидные микросателлитные участки (69), служащие в то же время наиболее эволюционно консервативными генетическими маркерами ДНК.

Примерно до середины 1990-х годов большая часть информации о популяционной структуре и родстве у социальных насекомых основывались на данных об аллозимах (70). Первый прецедент использования ДНК маркеров состоял в изучении полиморфизма сайтов рестрикции генов рибосомальной РНК у ос рода Polistes (71), и с тех пор применение таких маркеров стремительно расширялось. Это связано с тем, что микросателлитные локусы имеют ряд преимуществ: они многочисленны, гипервариабельны, чрезвычайно информативны и широко представлены по всему геному. Микросателлитные локусы - очень удобный инструмент для анализа генетической структуры популяций, оценки гетерозиготности, степени инбридинга, определения коэффициентов генетического родства, вычисления генетических дистанций между популяциями и подвидами и оценки включения чужеродных генов одних видов в генные комплексы других. Первые микросателлитные локусы у Apis mellifera были описаны в 1993 году (72). Микросателлитные маркеры благодаря наследованию от обоих родителей дают более полное представление о популяционных событиях, поэтому они активно используются для оценки интрогрессивной гибридизации в результате спаривания трутней и маток (32).

Таким образом, анализ полиморфизма микросателлитных локусов стал важным и востребованным методом популяционно-генетических исследований $A$. mellifera во всем мире, к настоящему времени описано около 552 полиморфных генетических маркеров (73). Микросателлиты обильно 
представлены в геноме медоносной пчелы, что позволило создать для A. mellifera L. первую карту сцепления на их основе. Она была получена преимущественно с использованием потомства двух гибридных маток (A. $m$. ligustica $\times A . m$. mellifera). В процессе реализации проекта был картирован 541 локус, включая 474 микросателлитных маркера, и выделены 24 группы сцепления. Усредненная плотность маркеров достигала 7,5 cM, а разрешение составляло один маркер на каждые 300 т.п.н. генома (74). В геноме медоносной пчелы 60 \% всех микросателлитов приходится на кодирующую область, при этом 50 \% тринуклеотидных и $25 \%$ динуклеотидных повторов расположены в экзонах (75). Все эти локусы полиморфные. Более того, многие из них успешно амплифицируются у трех других видов рода Apis A. cerana (58 \%), A. dorsata (59 \%) и A. florea (38 \%). Для получения статистически значимой оценки структуры популяции медоносной пчелы, а также для отнесения особей неизвестного происхождения к популяциям на основании генетического расстояния между особями и популяциями достаточно изучить полиморфизм 10 микросателлитных маркеров у 30-50 рабочих особей (76). При использовании морфометрических методов для достижения такой же степени разрешения требуется обработка от 200 до 750 рабочих особей (77).

$\mathrm{K}$ настоящему времени на основании данных о степени полиморфизма STR локусов выявлены зоны интрогрессии между пчелами подвидов A. m. mellifera и A. m. ligustica в Альпах, в Норвегии и Швейцарии (30), в Польше (31), в популяциях африканизированных пчел в Центральной Америке (78). Определены зоны гибридизации между подвидами $A$. m. ligustica и A. m. mellifera на территории Северо-Западной Европы (21). Изучена структура популяций медоносных пчел в Испании (79-81). Проведенный филогенетический анализ подтвердил данные о существовании эволюционных ветвей у A. mellifera, соответствующих географическому происхождению ее подвидов, ранее полученные на основании морфометрических сведений и мтДНК-анализа $(82,83)$. Установлено происхождение популяций медоносной пчелы на территории Европы $(84,85)$, Ближнего Востока (86) и Африки (87). Предложены методы дифференциации популяций и подвидов пчел (88).

Работы с привлечением анализа полиморфизма микросателлитных маркеров широко проводились не только для решения задач популяционной генетики рода Apis, но и для изучения других биологических аспектов, таких как частота спаривания (89), синдром анархии (90) и контроль репродуктивного доминирования (91).

В настоящее время возрастает интерес к изучению генетической структуры популяций A. mellifera и в развивающихся странах. Так, популяции аборигенного для Саудовской Аравии подвида медоносной пчелы $A . m$. jemenitica (92) изучены с использованием микросателлитных маркеров A7, A24, A28, A88, A113, В124, Ар43 и Ар81 с целью выяснения степени интрогрессии и гибридизации с пчелами активно импортируемых в страну подвидов (93). В результате был выявлен незначительный дефицит гетерозигот в субпопуляциях и более высокий их дефицит в общей популяции $A . m$. jemenitica $(\mathrm{FIS}=0,123$, FST $=0,009$ и FIT $=0,13)$. Интрогрессия носила двунаправленный характер и была более частой в некоторых регионах по сравнению с другими. При этом структурный анализ не выявил различных субпопуляций среди образцов аборигенных пчел. Высокое генетическое разнообразие местных медоносных пчел требует неотложного принятия программы сохранения целостности популяции.

С использованием анализа 8 микросателлитных маркеров был изу- 
чен полиморфизм трех популяций иранской медоносной пчелы $A$. m. meda на северо-западе Ирана. В популяциях из провинций Ardabil, Ardabil sharqi и Ardabil gharbi обнаружено соответственно семь, пять и четыре полиморфных микросателлитных маркера (94). Суммарное число наблюдаемых аллелей - 42. Пчелы из провинции Ardabil sharqi обладали наивысшей степенью гетерозиготности $(0,563)$, а наименышая была определена для популяции из провинции Ardabil gharbi $(0,438)$. В целом на основании оценки FST авторами была выявлена низкая степень генетической дивергенции между популяциями медоносных пчел в Северо-Западном Иране.

Интересные результаты были получены при изучении генетических характеристик популяции медоносной пчелы острова Родригес, расположенного в юго-западной части Индийского океана. При исследовании 524 пчелиных семей из 20 различных районов острова с использованием 18 микросателлитных маркеров все особи были успешно генотипированы как минимум по 10 локусам (95). Число наблюдаемых аллелей на локус составляло от 3 (для АР273) до 15 (для А029). Генетическое разнообразие, выраженное как представленность аллелей, варьировало между разными местами сбора образцов от 4,75 $\pm 1,58$ до $5,09 \pm 1,38$. Таким образом, анализ ядерной ДНК показал, что медоносные пчелы на острове Родригес представляют собой одну генетически гомогенную популяцию. Это может быть связано с тем, что расстояния между оседлыми семьями чрезвычайно малы для создания генетической изоляции (от 0,6 до 13,8 км). Однако степень генетического разнообразия у исследованной популяции сопоставима с таковой у популяций $A$. $m$. ligustica и $A$. $m$. carnica в континентальной Европе. При этом популяция пчел острова Родригес, в отличие от остального мира, не испытывала сильного биологического давления, вызванного паразитами и патогенами (96), что может объяснять факт ее гораздо более высокой гетерозиготности по сравнению с популяциями других островных систем, куда была интродуцирована $A$. m. ligistica $(79,97)$.

Генетическое разнообразие островных популяций также изучено на примере Балеарских островов, где проанализировали 98 пчелиных семей из 22 районов архипелага с использованием восьми полиморфных микросателлитных локусов - В124, А113, А7, А35, А24, А28, А88 и А8. При этом была выявлена низкая вариабельность, определенная как на основании наблюдаемого числа аллелей, так и гетерозиготности, что ожидаемо для островных популяций (81). Несмотря на низкую степень генетической дифференциации внутри островов, имеет место значительный дефицит гетерозигот, указывающий на существование субпопуляционной генетической структуры. Популяции медоносной пчелы Балеарских остров разделяются на два кластера - Gimnesias (острова Мальорка и Менорка) и Pitiusas (острова Ибица и Форментера), что согласуется с биогеографической гипотезой, постулированной для этого архипелага. Филогенетический анализ подтвердил иберийское происхождение медоносных пчел Балеарских островов, поддерживая тем самым эволюционный сценарий для Apis mellifera в Средиземноморском бассейне, согласно которому A. m. iberica - это гибрид между африканским подвидом $A$. m. intermissa и темной европейской пчелой $A . m$. mellifera $(83,87)$.

При изучении генетической структуры и разнообразия 414 рабочих пчел из 8 алжирских популяций с использованием 14 полиморфных микросателлитных локусов было обнаружено существенное генетическое разнообразие как по числу аллелей, так и по степени гетерозиготности. Число аллелей в исследованных локусах варьировало от 2 (В24) до 22 (Ар43). Большинство популяций при этом находились в равновесии по Харди-Вайн- 
бергу. Было установлено, что алжирские пчелы представлены двумя подвидами - A. m. intermissa и A. m. sahariensis. (98). Проведенный филогенетический анализ поместил их в обособленную от эволюционных линий М, С и О группу (99). Данные о полиморфизме микросателлитных локусов в алжирских популяциях медоносных пчел, а также в референсных популяциях, исследованных ранее $(82,85,98,100)$, позволили провести кластеризацию этих популяций, в результата получили пять групп в зависимости от происхождения: линии М (Франция, Бельгия), О (Армения, Грузия), С (Греция, Италия) и А (Марокко, Гвинея), а также алжирскую группу, принадлежащую к африканской эволюционной ветви А. При этом африканские популяции медоносных пчел характеризуются высокой степенью полиморфизма микросателлитных локусов ДНК, что стало результатом ярко выраженного миграционного поведения и тенденции к роению (83). Для некоторых алжирских популяций была обнаружена незначительная интрогрессия эволюционных линий М и С.

Полиморфные STR локусы активно используются при изучении генетической структуры автохтонных популяций медоносной пчелы в различных регионах Российской Федерации: популяций гибридных пчел Томской области (101) и популяций A. m. mellifera Пермского края (102), Республики Башкортостан (103), Архангельской и Владимирской областей, Красноярского края и Республики Татарстан (104); популяций A. m. carpatica Республики Адыгея (105); популяций A. m. caucasica Орловской области и Краснодарского края (105), гибридных пчел Новосибирской области (107).

Для оценки вариабельности микросателлитных локусов А008, Ap049, AC117, АС216 у медоносных пчел, обитающих на территории Томской области, сформировали 4 выборки (среднерусская и карпатская пчела, гибриды различного происхождения) на основе проведенных ранее мтДНКи морфометрического анализа. В изученных локусах выборки среднерусской и карпатской пород различались по наблюдаемым аллельным вариантам и частотам их встречаемости. При этом спектр аллелей, выявленных для пчел среднерусской породы, наблюдался в полной мере и у гибридов на основе среднерусской и карпатской пород (101). На основании анализа полиморфизма 9 микросателлитных локусов ядерной ДНК среди более чем 300 образцов ДНК пчелиных семей, собранных на севере Республики Татарстан, Республики Башкортостан и территории Пермского края, была изучена популяционно-генетическая структура медоносной пчелы подвида A. m. mellifera. Результаты молекулярно-генетических анализов позволяют предположить существование на Урале достаточно устойчивой сохранившейся популяционной системы темной лесной пчелы, возможно, последней в мире (102).

Результаты анализа генетической структуры популяции медоносной пчелы в южной части Башкортостана на основании полиморфизма пяти микросателлитных локусов ядерной ДНК (Аp243, 4A110, A8, A113 и А28) свидетельствуют, что интенсивная межпородная гибридизация, на наличие которой указывает среднее значение FIS, еще не привела к исчезновению дефицита гетерозигот. Значение степени подразделенности субпопуляций, полученное авторами, позволило предположить наличие границы между гибридной зоной и популяцией $A$. m. mellifera, локализованной в изучаемом регионе (103). Исследованные пчелиные семьи были дифференцированы на три группы. Вероятно, что периферийной части популяции $A . m$. mellifera соответствуют кластеры Zil1 и Zil2, однако вопрос ее родства с бурзянской популяцией остался открытым. К периферийной части другой локальной популяции среднерусской пчелы можно отнести кластер Haib4. 
Месторасположение гибридной межпородной зоны отражают остальные кластеры.

При оценке изменчивости аллелофонда STR маркеров в процессе формирования специализированных линий медоносной пчелы приокского типа среднерусской породы изучили микросателлитные профили у шести пчелосемей каждой из двух линий - Клевер (отбор по эффективности опыления клевера лугового) и IV-3T (селекция по зимостойкости) (104). В выборке из 88 особей наблюдаемое число аллелей на локус в среднем соста-

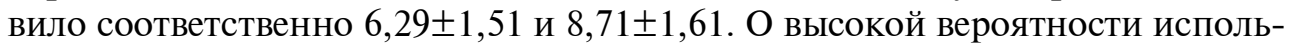
зования инбридинга при разведении пчел приокский типа убедительно свидетельствует дефицит гетерозигот, достигавший соответственно 24,5 и $10,8 \%$. Было установлено, что 85,7 \% особей линии Клевер и 86,8 \% особей линии IV-3T могут быть генетически отнесены к собственным популяциям на основании анализа микросателлитов. Как следует из расчета индекса фиксации Rst (AMOVA), 23 \% всей изменчивости обусловлено межпопуляционными различиями, 77 \% - внутрипопуляционной изменчивостью. Убедительно показано, что микросателлитный анализ полностью применим при создании специализированных линий медоносных пчел, так как отбор таких линий всегда сопровождается изменением аллелофонда микросателлитов.

Также проводились работы по изучению информативности тест-системы, разработанной для анализа 7 микросателлитных локусов (А024, А88, A113, АР043, НВ-C16-05, НВ-ТНЕ-03 и НВ-С16-01). Она была использована для исследования основных параметров аллелофонда популяций медоносных пчел серой горной кавказской $(n=70)$ и среднерусской $(n=65)$ пород, а также приокского типа среднерусской породы $(n=88)(105)$. Установлено, что среднее число аллелей на локус составляет $7,48 \pm 1,02$, число

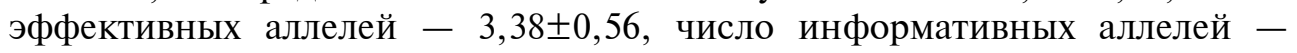
$3,62 \pm 0,71$. По сравнению с популяциями среднерусской и серой горной кавказской пород, участвовавших в выведении приокского типа, у последнего выявлено повышенное генетическое разнообразие аллелофонда $(9,57 \pm 1,88$ против $6,86 \pm 1,55$ и $6,00 \pm 1,84)$. Подтверждена интродукция аллелей исходных пород в аллелофонд пчел приокского типа, процесс генетической консолидации которого, однако, еще не завершен. Установлено, что на долю межпопуляционных различий приходится $8 \%$ от общего аллельного разнообразия.

Чистопородность и дифференциацию основных пород пчел, разводимых на территории Российской Федерации, оценивали на основании полиморфизма микросателлитных маркеров ядерной ДНК, используя мультиплексный анализ восьми локусов - АO24, А88, А113, АPO43, APхO1, НВC16-05, НВ-ТНЕ-03 и НВ-С16-01 (106). О высокой степени изолированности карпатской породы пчел свидетельствовало наличие наибольшего числа приватных аллелей. При этом существенных различий по числу приватных аллелей между среднерусской и серой горной кавказской породами не обнаружили. Анализ STR маркеров продемонстрировал в среднем высокую идентичность особей в изученных породах (99 \%). Наименышей степенью консолидированности характеризовалась карпатская порода (97,0 \%), а наиболее консолидированной была среднерусская порода (100 \%). Расчет генетических расстояний показал, что наиболее близки друг к другу серая горная кавказская и карпатская породы медоносной пчелы, формирующие единый кластер на филогенетическом дереве.

Сравнение аллелофонда у дальневосточной популяции медоносной пчелы, интродуцированной в Новосибирскую область $(n=90)$, и у популяций среднерусской $(n=191, A$. m. mellifera $)$, серой горной кавказской $(n=113$, 
A. m. caucasica), краинской $(n=61, A . m$. carnica) и карпатской $(n=184$, A. m. carpatica) пород выполняли по семи локусам микросателлитов (107). Степень генетической дифференциации новосибирской популяции оценивали, используя индексы Fst, Rst (AMOVA) и генетические дистанции по Nei. B результате показано, что новосибирская популяция дальневосточных пчел характеризуется высокой степенью генетического разнообразия и, будучи метизированной, наиболее близка по происхождению к краинской. Учитывая происхождение дальневосточных пчел от украинской степной породы, полученные данные можно рассматривать как косвенное подтверждение близкого родства украинской степной и краинской пород (107).

Анализ микросателлитных профилей с целью молекулярно-генетической дифференциации линий и семей медоносной пчелы $A$. m. caucasica, разводимых в районе Большого Сочи, выявил сходные тенденции при оценке внутри- и межсемейной изменчивости (106). В качестве указания на высокую гетерогенность I линии можно рассматривать наблюдаемый избыток гетерозигот (FIS $=-0,048)$. Представители этой линии характеризовались максимальной межсемейной $(\mathrm{FST}=0,124)$ и минимальной индивидуальной $\left(\mathrm{F}_{\mathrm{IT}}=0,052\right)$ изменчивостью. Для II-V линий была характерна относительно высокая индивидуальная изменчивость (FIT от 0,143 до 0,189) при наблюдаемом дефиците гетерозигот (FIS от 0,062 до 0,128), а также существенно более низкие значения межсемейной изменчивости по отношению к I линии (FsT от 0,095 до 0,104). B III и IV линиях отмечены наименьшие межсемейные различия (FST $=0,096$ и FsT $=0,095)$ среди всех изученных групп. Дифференциация изучаемых линий по морфометрическим признакам и STR маркерам позволила выявить некоторые различия в структуре генеалогического дерева. Географическая удаленность линий друг от друга отражалась на дендрограмме, построенной на основании анализа с использованием микросателлитных маркеров.

Важнейшее условие для развития и повышения продуктивности пчеловодческой отрасли - поддержание биоразнообразия медоносной пчелы. Региональные популяции могут представлять собой значительный резерв для его пополнения. С использованием семи микросателлитов (А024, А88, A113, АР043, НВ-C16-05, НВ-ТНЕ-03, НВ-С16-01) были определены ключевые характеристики аллелофонда приморской популяции дальневосточной пчелы и оценена степень ее генетической дифференциации (109). Материалом служили рабочие пчелы дальневосточной популяции (DALN) $(n=143)$. При попарном сравнении использовали величины D и FsT. Формируя группы сравнения, чистопородных пчел отбирали на основании ко-

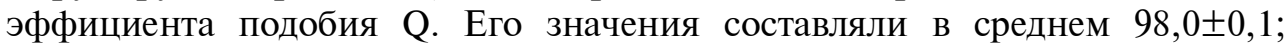
$97,9 \pm 0,2 ; 98,1 \pm 0,1$ и 95,8 $\pm 0,4 \%$ соответственно для серой горной кавказской (SGK, $n=70)$, среднерусской (SR, $n=61)$, карпатской (KARP, $n=55)$ и краинской (CAR, $n=30)$ пород. Характерное для групп сравнения относительно высокое генетическое разнообразие (для KARP $-12,43 \pm 2,71$, для

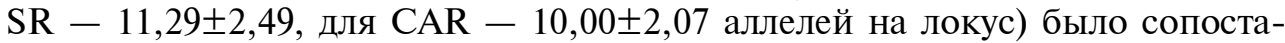
вимо с таковым в исследуемой выборке DALN $(11,14 \pm 1,30$ аллелей на локус). Эффективное число аллелей, рассчитанное для группы DALN, превышало значение, характерное для остальных групп (4,94 аллеля против 3,194,51 аллеля). Дефицит гетерозигот был наибольшим в популяции дальневосточных пчел (FIS $=0,32)$, практически такой же показатель отмечали у среднерусской породы (FIS = 0,31). Данные ДНК-анализа стали основанием для отнесения 96,5 \% особей выборки DALN к собственной популяции. Высокая степень генетической консолидации дальневосточной породы может выступать индикатором практически полного отсутствия потока генов 
между этой и остальными изученными породами. Дальневосточные пчелы формируют самостоятельную ветвь на генеалогическом дереве, что подтверждает их иное происхождение по сравнению с остальными породами в выборке. На основании полученных результатов дальневосточная пчела в 2018 году включена в Российский государственный реестр селекционных достижений в качестве самостоятельной породы медоносных пчел (заявка № 8356497, патентообладатель ФГБНУ ФНЦ агробиотехнологий Дальнего Востока им. А.К. Чайки).

Микросателлитные локусы также рассматривают в качестве инструмента для изучения особенностей репродукции медоносных пчел, в частности полиандрии. Полиандрия представляет собой специфическое явление, которое обеспечивает увеличение генетического разнообразия. В эксперименте по определению степени полиандрии и вклада трутней в генетическое разнообразие сравнивали микросателлитные профили по трем локусам (А008, Ap049, АC117) у гибридных и чистокровных пчелосемей A. mellifera (среднерусская и карпатская породы, Томская область) (110). Оказалось, что доля привнесенных в пчелосемью аллелей по линии самцов составляет 6,67-28,0 \%. Наибольшим генетическим разнообразием при этом характеризовались гибридные пчелосемьи (показана более высокая доля привнесенных аллелей по линии самцов - 25-28 \%).

Итак, медоносная пчела - вид, имеющий всемирное распространение (за исключением Антарктиды) и важнейшее экономическое, сельскохозяйственное и экологическое значение. Однако в последние несколько лет наблюдается глобальное снижение валового числа ульев медоносных пчел (с 21 до 15,5 млн), что создает угрозу не только для пчеловодства, но и для ряда отраслей растениеводства, а также для многих природных экосистем, стабильность которых поддерживается благодаря участию пчел в опылении дикорастущих растений. Причины такого снижения не вполне понятны, но могут быть связаны с потерей генетического разнообразия, синергетическими эффектами заражения паразитами (варроатоз и нозематоз), вирусными и бактериальными инфекциями, а также с широким использованием пестицидов в сельском хозяйстве. В этих условиях определение генетического разнообразия в популяциях медоносных пчел с помощью молекулярных методов приобретает первоочередное значение. Микросателлиты представлены короткими тандемными повторами (размер мономерного звена от 2 до 6 п.н.), рассеянными по всей ядерной ДНК. Они могут быть локализованы как в некодирующих (в том числе регуляторных) участках, так и в областях генома, кодирующих белки. Микросателлитные локусы представляют собой очень удобный инструмент для анализа генетической структуры популяций медоносных пчел, степени инбридинга и гетерозиготности, вычисления коэффициентов генетического родства и определения степени интрогрессии. С использованием микросателлитных маркеров раскрыта эволюционная история подвидов медоносных пчел, изучена структура большого числа их популяций в Старом и Новом Свете, выполнена оценка включения чужеродных генов одних подвидов в генные комплексы других, разработаны методы дифференциации подвидов и популяций. Большое число аллелей, характерное для микросателлитных локусов в связи с высокой частотой происходящих в них мутационных событий, и кодоминантный тип наследования делают STR маркеры чрезвычайно мощными средствами геномного картирования, определения достоверности происхождения, проведения популяционно-генетических и эволюционных исследований. 


\section{ЛИ Т Е РАТ У РА}

1. Aizen M.A., Garibaldi L.A., Cunningham S.A., Klein A.M. How much does agriculture depend on pollinators? Lesson from long-term trends in crop production. Annals of Botany, 2009, 103(9): 1579-1588 (doi: 10.1093/aob/mcp076).

2. Potts S.G., Roberts S.P., Dean R., Marris G., Brown M.A., Jones R., Neumann P., Settele J. Declines of managed honey bees and beekeepers in Europe. Journal of Apicultural Research, 2010, 49(1): 15-22 (doi: 10.3896/IBRA.1.49.1.02).

3. vanEngelsdorp D., Traynor K.S., Andree M., Lichtenberg E.M., Chen Y., Saegerman C., CoxFoster D.L. Colony Collapse Disorder (CCD) and bee age impact honey bee pathophysiology. PLoS ONE, 2017, 12(7): e0179535 (doi: 10.1371/journal.pone.0179535).

4. Wallberg A., Han F., Wellhagen G., Dahle B., Kawata M., Haddad N., Simões Z.L.P., Allsopp M.H., Kandemir I., De la Rúa P., Pirk C.W., Webster M.T. A worldwide survey of genome sequence variation provides insight into the evolutionary history of the honeybee Apis mellifera. Nature Genetics, 2014, 46: 1081-1088 (doi: 10.1038/ng.3077).

5. Chauzat M.P., Martel A.-C., Zeggane S., Drajunudel, Schurr F., Clément M.-C., RibièreChabert M., Aubet M., Faucon J.-P. A case control study and a survey on mortalities of honey bee colonies (Apis mellifera) in France during the winter of 2005-2006. Journal of Apicultural Research, 2010, 49(1): 40-51 (doi: 10.3896/IBRA.1.49.1.06).

6. EPILOBEE Consortium, Chauzat M.P., Jacques A., Laurent M., Bougeard S., Hendrikx P., Ribière-Chabert M. Risk indicators affecting honeybee colony survival in Europe: one year of surveillance. Apidologie, 2016, 47(3): 348-378 (doi: 10.1007/s13592-016-0440-z).

7. Johnson R.M., Ellis M.D., Mullin C.A., Frazier M. Pesticides and honey bee toxicity - USA. Apidologie, 2010, 41(3): 312-331 (doi: 10.1051/apido/2010018).

8. vanEngelsdorp D., Meixner M.D. A historical review of managed honey bee populations in Europe and the United States and the factors that may affect them. Journal of Invertebrate Pathology, 2010, 103(Suppl.): S80-S95 (doi: 10.1016/j.jip.2009.06.011).

9. Evans J.D., Aronstein K., Chen Y.P., Hetru C., Imler J.-L., Jiang H., Kanost M., Thompson G.J., Z. Zou, Hultmark D. Immune pathways and defense mechanisms in honey bees Apis mellifera. Insect Molecular Biology, 2006, 15(5): 645-656 (doi: 10.1111/j.1365-2583.2006.00682.x).

10. DeGrandi-Hoffman G., Chen Y. Nutrition, immunity and viral infections on honey bees. Current Opinion in Insect Science, 2015, 10: 170-176 (doi: 10.1016/j.cois.2015.05.007).

11. Larsen A., Reynaldi F.J., Guzmán-Novoa E. Fundamentals of the honey bee (Apis mellifera) immune system. Review. Revista Mexicana de Ciencias Pecuarias, 2019, 10(3): 705-728 (doi: 10.22319/rmcp.v10i3.4785).

12. Tsuruda J.M., Harris J.W., Bourgeois L., Danka R.G., Hunt G.J. High-resolution linkage analyses to identify genes that influence Varroa sensitive hygiene behavior in honey bees. PLoS ONE, 2012, 7(11): e48276 (doi: 10.1371/journal.pone.0048276).

13. Gisder S., Schüler V., Horchler L.L., Groth D., Genersch E. Long-term temporal trends of Nosema spp. infection prevalence in northeast Germany: continuous spread of Nosema ceranae, an emerging pathogen of honey bees (Apis mellifera), but no general replacement of Nosema apis. Frontiers in Cellular and Infection Microbiology, 2017, 7: 301 (doi: 10.3389/fcimb.2017.00301).

14. Nazzi F., Annoscia D., Caprio E., Di Prisco G., Pennacchio F. Honeybee immunity and colony losses. Entomologia, 2014, 2(2) (doi: 10.4081/entomologia.2014.203).

15. Smith K.M., Loh E.H., Rostal M.K., Zambrana-Torrelio C.M., Mendiola L., Daszak P. Pathogens, pests, and economics: drivers of honey bee colony declines and losses. EcoHealth, 2014, 10(4): 434-445 (doi: 10.1007/s10393-013-0870-2).

16. Rosenkranz P., Aumeier P., Ziegelmann B. Biology and control of Varroa destructor. Journal of Invertebrate Pathology, 2010, 103(Suppl.): S96-S119 (doi: 10.1016/j.jip.2009.07.016).

17. Rangel J., Baum K., Rubink W.L., Coulson R.N., Johnston J.S., Traver B.E. Prevalence of Nosema species in a feral honey bee population: a 20-year survey. Apidologie, 2016, 47: 561-571 (doi: 10.1007/s13592-015-0401-y).

18. Кривцов Н.И. Генофонд пчел Apis mellifera mellifera в России. Мат. Межд. конф. «Пчеловодство - ХХІ век. Темная пчела (Apis mellifera L.) в Pоссии». M., 2008: 22-27.

19. Саттаров В.Н. Пути сохранения башкирской популяции среднерусской породы пчел. Пчеловодство, 2012, 9: 12-13.

20. Ильясов Р.А., Поскряков А.В., Николенко А.Г. Основные методы идентификации подвидов пчел Apis mellifera. Биомика, 2017, 9(2): 71-90.

21. Jensen A.B., Palmer K.A., Boomsa J.J., Pedersen B.V. Varying degrees of Apis mellifera ligustica introgression in protected populations of the black honey bee, Apis mellifera mellifera, in north west Europe. Molecular Ecology, 2005, 14: 93-106 (doi: 10.1111/j.1365-294X.2004.02399.x).

22. Колбина Л.М., Непейвода С.Н. Породный состав пчел Удмуртии. Пчеловодство, 2009, 5: 6-7.

23. Бородачев А.В., Савушкина Л.Н. Сохранение и рациональное использование генофонда 
пород медоносной пчелы. Пчеловодство, 2012, 4: 3-5.

24. Бородачев А.В., Савушкина Л.Н. Породы и типы пчел для разведения в Сибири. Mam. регион. науч.-практ. конф. «Современное состояние и перспективы развития пчеловодства в Сибири». Красноярск, 2015: 24-29.

25. Ильясов Р.А., Поскряков А.В., Николенко А.Г. Преимущества темной лесной пчелы Apis mellifera mellifera и ее значимость для России. Биомика, 2017, 9(2): 83-90.

26. Engel M.S. The taxonomy of recent and fossil honey bees (Hymenoptera: Apidae; Apis). Journal of Hymenoptera Research, 1999, 8(2): 165-196.

27. Meixner M.D., Leta M.A., Koeniger N., Fuchs S. The honey bees of Ethiopia represent a new subspecies of Apis mellifera - Apis mellifera simensis n. spp. Apidologie, 2011, 42: 425-437 (doi: 10.1007/s13592-011-0007-y).

28. Cridland J.M., Tsutsui N.D., Ramírez S.R. The complex demographic history and evolutionary origin of the Western honey bee, Apis mellifera. Genome Biol. Evol., 2017, 9(2): 457-472 (doi: 10.1093/gbe/evx009).

29. Pinto M.A., Henriques D., Chávez-Galarza J., Kryger P., Garnery L., van der Zee R., Dahle B., Soland-Reckeweg G., de la Rúa P., Dall' Olio R., Carreck N.L., Johnson J.S. Genetic integrity of the Dark European honey bee (Apis mellifera mellifera) from protected populations: a genomewide assessment using SNPs and mtDNA sequence data. Journal of Apicultural Research, 2014, 53(2): 269-278 (doi: 10.3896/IBRA.1.53.2.08).

30. Soland-Reckeweg G., Heckel G., Neumann P., Fluri P., Excoffier L. Gene flow in admixed populations and implications for the conservation of the Western honey bee, Apis mellifera. Journal of Insect Conservation, 2009, 13: 317-328 (doi: 10.1007/s10841-008-9175-0).

31. Oleksa A., Chybicki I., Tofilski A., Burczyk J. Nuclear and mitochondrial patterns of introgression into native dark bees (Apis mellifera mellifera) in Poland. Journal of Apicultural Research, 2011, 50(2): 116-129 (doi: 10.3896/IBRA.1.50.2.03).

32. De la Rúa P., Jaffé R., Dall’Olio R., Muňnoz I., Serrano J. Biodiversity, conservation and current threats to European honeybees. Apidologie, 2009, 40: 263-284 (doi: 10.1051/apido/2009027).

33. Meixner M.D., Costa C., Kryger P., Hatjina F., Bouga M., Ivanova E., Büchler R. Conserving diversity and vitality for honey bee breeding. Journal of Apicultural Research, 2010, 49(1): 85-92 (doi: 10.3896/IBRA.1.49.1.12).

34. Jaffé R., Dietman V., Alssopp M., Costa C., Crew R., Dall’Olio R., De la Rúa P., El-Niweiri Mogbel A.A., Fries I., Kezic N., Meusel M., Paxton R.J., Shaibi T., Stolle E., Moritz R.F.A. Estimating the density of honeybee colonies across their natural range to fill the gap in pollinator decline censuses. Conservation Biology, 2009, 24(2): 583-591 (doi: 10.1111/j.15231739.2009.01331.x).

35. Kauhausen-Keller D., Keller R. Morphometrical control of pure race breeding of honeybee (Apis mellifera L.). Apidologie, 1994, 25(2): 133-143 (doi: 10.1051/apido:19940202).

36. Maul V., Hähnle A. Morphometric studies with purebred stock of Apis mellifera carnica Pollmann from Hessen. Apidologie, 1994, 25: 119-132.

37. Ильясов Р.А., Поскряков А.В., Петухов А.В., Николенко А.Г. Молекулярно-генетический анализ пяти сохранившихся резерватов темной лесной пчелы Apis mellifera mellifera Урала и Поволжья. Генетика, 2016, 52(8): 931-943 (doi: 10.7868/S0016675816060059).

38. Rhymer J.M., Simberloff D. Extension by hybridization and introgression. The Annual Review of Ecology, Evolution, and Systematics, 1996, 27: 83-109 (doi: 10.1146/annurev.ecolsys.27.1.83).

39. Кривцов Н.И., Горячева И.И., Бородачев А.В. Исследование пород и популяций медоносной пчелы (Apis mellifera L.) для разработки критериев генетической паспортизации пчел. Доклады Российской академии сельскохозяйственных наук, 2011, 1: 51-54.

40. Graur D. Gene diversity in Hymenoptera. Evolution, 1985, 38: 190-199 (doi: 10.1111/j.15585646.1985.tb04091.x).

41. Pamilo P., Crozier R.H. Genic variation in male haploids under deterministic selection. Genetics, 1981, 98(1): 199-214.

42. Pamilo P., Varvio-Aho S.-L., Pekkarinen A. Low enzyme variability in Hymenoptera as a consequence of haplodiploidy. Hereditas, 1978, 88(1): 93-99 (doi: 10.1111/j.1601-5223.1978.tb01607.x).

43. Shoemaker D.D., Costa J.T., Ross K.G. Estimates of heterozygosity in two social insects using a large number of electrophoretic markers. Heredity, 1992, 69: 573-582 (doi: 10.1038/hdy.1992.173).

44. Rowe D.J., Rinderer T.E., Stelzer J.A., Oldroyd B.P., Crozier R.H. Seven polymorphic microsatellite loci in honeybees (Apis mellifera). Insectes Sociaux, 1997, 44: 85-93 (doi: $10.1007 / \mathrm{s} 000400050032$ ).

45. Jeffreys A.J., Wilson V., Thein S.L. Individual-specific "fingerprints" of human DNA. Nature, 1985, 316: 76-79 (doi: 10.1038/316076a0).

46. Weber J.L., Wong C. Mutation of human short tandem repeats. Human Molecular Genetics, 1993 , 2(8): 1123-1128 (doi: 10.1093/hmg/2.8.1123).

47. Sheppard W.S., Smith D.R. Identification of African-derived bees in the Americas: a survey of methods. Annals of the Entomological Society of America, 2000, 93(2): 159-176 (doi: 10.1603/00138746(2000)093[0159:IOADBI]2.0.CO;2).

48. López-Flores I., Garrido-Ramos M.A. The repetitive DNA content of eukaryotic genomes. 
Genome Dynamics, 2012, 7: 1-28 (doi: 10.1159/000337118).

49. Ellegren H. Microsatellites: simple sequences with complex evolution. Nature Reviews Genetics, 2004, 5: 435-445 (doi: 10.1038/nrg1348).

50. Rosenberg N.A., Pritchard J.K., Weber J.L., Cann H.M., Kidd K.K., Zhivotovsky L.A., Feldman M.W. Genetic structure of human populations. Science, 2002, 298(5602): 2381-2385 (doi: 10.1126/science.1078311).

51. Ellegren H. Microsatellite mutations in the germline: implication for evolutionary inference. Trends in Genetics, 2000, 16(12): 551-558 (doi: 10.1016/s0168-9525(00)02139-9).

52. SantaLucia J.Jr., Hicks D. The thermodynamics of DNA structural motifs. Annual Review of Biophysics and Biomolecular Structure, 2004, 33: 415-440 (doi: 10.1146/annurev.biophys.32.110601.141800).

53. Fan H., Chu J.-Y. A brief review of short tandem repeat mutation. Genomics Proteomics Bioinformatics, 2007, 5(1): 7-14 (doi: 10.1016/S1672-0229(07)60009-6).

54. Di Rienzo A., Peterson A.C., Garza J.C., Valdes A.M., Slatkin M., Freimer N.B. Mutational processes of simple-sequence repeat loci in human populations. Proceedings of the National Academy of Sciences, 1994, 91(8): 3166-3170 (doi: 10.1073/pnas.91.8.3166).

55. Kruglyak S., Durrett R.T., Schug M.D., Aquadro C.F. Equilibrium distributions of microsatellite repeat length resulting from a balance between slippage events and point mutations. Proceedings of the National Academy of Sciences, 1998, 95(18): 100774-10778 (doi: 10.1073/pnas.95.18.10774).

56. Wells R.D. Molecular basis of genetic instability of triplet repeats. The Journal of Biological Chemistry, 1996, 271(6): 2875-2878 (doi: 10.1074/jbc.271.6.2875).

57. Anselmi C., Bocchinfuso G., De Santis P., Savino M., Scipioni A. A theoretical model for the prediction of sequence-dependent nucleosome thermodynamic stability. Biophysical Journal, 2000, 79(2): 601-613 (doi: 10.1016/S0006-3495(00)76319-3).

58. Owczarzy R., Vallone P.M., Gallo F.J., Paner T.M., Lane M.J., Benight A.S. Predicting sequence-dependent melting stability of short duplex DNA oligomers. Biopolymers, 1997, 44(3): 217-239 (doi: 10.1002/(SICI)1097-0282(1997)44:3<217::AID-BIP3>3.0.CO;2-Y).

59. Valdes A.M., Slatkin M., Freimer N.B. Allele frequencies at microsatellite loci: the stepwise mutation model revisited. Genetics, 1993, 133(3): 737-749.

60. Калюжный Д.Н., Бондарев Ф.С., Щелкина А.К., Лившиц М.А., Борисова О.Ф. Внутримолекулярные $\mathrm{G}$-квадруплексы, образованные микросателлитной последовательностью $\mathrm{d}(\mathrm{GT}) 12$ в присутствии ионов $\mathrm{K}^{+}$. Молекулярная биология, 2008, 42(1): 693-700.

61. Сиянова Е.Ю., Миркин С.М. Экспансия тринуклеотидных повторов. Молекулярная биология, 2001, 35(2): 208-223.

62. Омельченко А.В. Молекулярная характеристика локусов, содержащих динуклеотидные микросателлиты, генома партеногенетической ящерицы Darevsia uniseхиаlis: монография. M., 2013.

63. Sturzeneker R., Haddar L.A., Bevilacqua A.U., Simpson A.J.G., Pena S.D.J. Polarity of mutations in tumor-associated microsatellite instability. Human Genetics, 1998, 102: 231-235 (doi: 10.1007/s004390050684).

64. Coloson I., Goldstein D.B. Evidence for complex mutations at microsatellite loci in Drosophilla. Genetics, 1999, 152(2): 617-627.

65. Orti G., Pearse D.E., Avise J. Phylogenetic assessment of length variation at a microsatellite locus. Proceedings of the National Academy of Sciences, 1997, 94(20): 10745-10749 (doi: 10.1073/pnas.94.20.10745).

66. Зимницкий А.Н., Башкатов С.А., Уразбаев В.Н. Тандемные повторы ДНК и концепция матричного синтеза протеогликанов. М., 2005.

67. Neff B.D., Gross M.R. Microsatellite evolution in vertebrates: inference from AC dinucleotide repeats. Evolution, 2001, 55(9): 1717-1733 (doi: 10.1111/j.0014-3820.2001.tb00822.x).

68. Животовский Л.А. Микросателлитная изменчивость в популяциях человека и методы ее изучения. Вестник ВОГи С, 2006, 10(1): 74-96.

69. Sharma P.C., Grover A., Kahl G. Mining microsatellites in eukaryotic genomes. Trends in Biotechnology, 2007, 25(11): 490-498 (doi: 10.1016/j.tibtech.2007.07.013).

70. Crozier R.H., Pamilo P. Evolution of social insect colonies. Sex allocation and kin-selection. Oxford University Press, UK, 1996.

71. Davis S.K., Strassmann J.E., Hughes C., Pletscher L.S., Templeton A.R. Population structure and kinship in Polistes (Hymenoptera, Vespidae): an analysis using ribosomal DNA and protein electrophoresis. Evolution, 1990, 44: 1242-1253 (doi: 10.1111/j.1558-5646.1990.tb05228.x).

72. Estoup A., Solignac M., Harry M., Cornuet J.M. Characterization of (GT)n and (CT)n microsatellites in two insect species: Apis mellifera and Bombus terrestris. Nucleic Acids Research, 1993, 21(6): 1427-1431 (doi: 10.1093/nar/21.6.1427).

73. Solignac M., Vautrin D., Loiseau A., Mougel F., Baudry E., Estoup A., Garnery L., Haberl M., Cornuet J.-M. Five hundred and fifty microsatellite markers for the study of the honeybee (Apis mellifera) genome. Molecular Ecology Notes, 2003, 3(2): 307-311 (doi: 10.1046/j.14718286.2003.00436.x).

74. Solignac M., Vautrin D., Baudry E., Mougel F., Loiseau A., Cornuet J.-M. A microsatellite- 
based linkage map of the honeybee, Apis mellifera L. Genetics, 2004, 167(1): 253-262 (doi: 10.1534/genetics.167.1.253).

75. Archak S., Meduri E., Kumar P.S., Nagaraju J. InSatDb: a microsatellite database of fully sequenced insect genomes. Nucleic Acids Research, 2007, 35(Suppl_1): D36-D39 (doi: 10.1093/nar/gkl778).

76. Cornuet J.M., Piry S., Luikart G., Estoup A., Solignac M. New methods employing multilocus genotypes to select or exclude populations as origins of individuals. Genetics, 1999, 153(4): 1989-2000.

77. Bodur C. Genetic structure analysis of honeybee populations based on microsatellites. Ph.D Thesis. Ankara, 2005.

78. Clarke K.E., Rinderer T.E., Franck P., Quezada-Euán J.J.G., Oldroyd B.P. The Africanization of honey bees (Apis mellifera) of the Yucatan: a study of a massive hybridization event across time. Evolution, 2002, 52(7): 1462-1474 (doi: 10.1111/j.0014-3820.2002.tb01458.x).

79. De la Rúa P., Galián J., Serrano J., Moritz R.F.A. Genetic structure and distinctness of Apis mellifera L. populations from Canary Islands. Molecular Ecology, 2001, 10(7): 1733-1742 (doi: 10.1046/j.1365-294x.2001.01303.x).

80. De la Rúa P., Galián J., Serrano J., Moritz R.F.A. Microsatellite analysis of non-migratory colonies of Apis mellifera iberica from south-eastern Spain. Journal of Zoological Systematics and Evolutionary Research, 2002, 40(3): 164-168 (doi: 10.1046/j.1439-0469.2002.00187.x).

81. De la Rúa P., Galián J., Serrano J., Moritz R.F.A. Genetic structure of Balearic honeybee populations based on microsatellite polymorphism. Genetics Selection Evolution, 2003, 35: 339-350 (doi: 10.1186/1297-9686-35-3-339).

82. Estoup A., Garnery L., Solignac M., Cornuet J.M. Microsatellite variation in honey bee (Apis mellifera L.) populations: hierarchical genetic structure and test of the infinite allele and stepwise mutation models. Genetics, 1995, 140(2): 679-695.

83. Franck P., Garnery L., Solignac M., Cornuet J.M. The origin of west European subspecies of honeybees (Apis mellifera): new insights from microsatellite and mitochondrial data. Evolution, 1998, 52(4): 1119-1134 (doi: 10.2307/2411242).

84. Franck P., Garnery L., Celebrano G., Solignac M., Cornuet J.-M. Hybrid origins of honey bees from Italy (Apis mellifera mellifera) and Sicily (A. m. sicula). Molecular Ecology, 2000, 9(7): 907921 (doi: 10.1046/j.1365-294x.2000.00945.x).

85. Sušnik S., Kozmus P., Poklukar J., Meglič V. Molecular characterisation of indigenous Apis mellifera carnica in Slovenia. Apidologie, 2004, 35(6): 623-636 (doi: 10.1051/apido:2004061).

86. Franck P., Gernery L., Solignac M., Cornuet J.-M. Molecular confirmation of a fourth lineage in honeybees from the Near East. Apidologie, 2000, 31(2): 167-180 (doi: 10.1051/apido:2000114).

87. Franck P., Garnery L. Loiseau A., Oldroyd B.P., Hepburn H.R., Solignac M., Cornuet J.-M. Genetic diversity of the honey bee in Africa: microsatellite and mitochondrial data. Heredity, 2001, 86: 420-430 (doi: 10.1046/j.1365-2540.2001.00842.x).

88. Meixner M.D., Pinto M.A., Bouga M., Kryger P., Ivanova E., Fuchs S. Standard methods for characterising subspecies and ecotypes of Apis mellifera. Journal of Apicultural Research, 2013, 52(4): 1-28 (doi: 10.3896/IBRA.1.52.4.05).

89. Palmer K.A., Oldroyd B.P. Evolution of multiple mating in the genus Apis. Apidologie, 2000, 31(2): 235-248 (doi: 10.1051/apido:2000119).

90. Châline N., Ratnieks F.L.W., Burke T. Anarchy in the UK: Detailed genetic analysis of worker reproduction in a naturally occurring British anarchistic honeybee, Apis mellifera, colony using DNA microsatellites. Molecular Ecology, 2002, 11(9): 1795-1803 (doi: 10.1046/j.1365294X.2000.01569.x).

91. Lattorff H.M.G., Moritz R.F.A., Crewe R.M. Solignac M. Control of reproductive dominance by the thelytoky gene in honeybees. Biology Letters, 2007, 3(3): 292-295 (doi: 10.1098/rsbl.2007.0083).

92. Alqarni A.S., Hannan M.A., Owayss A.A., Engel M.S. The indigenous honey bees of Saudi Arabia (Hymenoptera, Apidae, Apis mellifera jemenitica Ruttner): their natural history and role in beekeeping. ZooKeys, 2011, 134: 83-98 (doi: 10.3897/zookeys. 134.1677).

93. Alattal Y., AlGhamdi A., Alsharhi M. Population structure of the Yemeni honey bee (Apis mellifera jemenitica) entails an urgent conservation strategy in Saudi Arabia. Journal of Entomology, 2014, 11(3): 163-169 (doi: 10.3923/je.2014.163.169).

94. Ghassemi-Khademi T., Rajabi-Maham H., Pashaei-Rad S. Genetic diversity evaluation of Persian honeybees (Apis mellifera meda) in North West of Iran, using microsatellite markers. Journal of Wildlife and Biodiversity, 2018, 2(2): 37-46 (doi: 10.22120/jwb.2018.86877.1026).

95. Techer M.A., Clémencet J., Turpin P., Volbert N., Reynaud B., Delatte H. Genetic characterization of the honeybee (Apis mellifera) population of Rodrigues Island, based on microsatellite and mitochondrial DNA. Apidologie, 2015, 46: 445-454 (doi: 10.1007/s13592-014-0335-9).

96. Esnault O., Meenowa D., Sookar P., Chauzat M.-P., Delatte H. Spread and strain determination of Varroa destructor following its introduction to Mauritius and interactions with the bee louse Braula pretoriensis in honey bee colonies. Journal of Apicultural Research, 2019, 58(1): 75-83 (doi: 10.1080/00218839.2018.1517987). 
97. De la Rúa P., Galián J., Pedersen B.V., Serrano J. Molecular characterization and population structure of Apis mellifera from Madeira and the Azores. Apidologie, 2006, 37(6): 699-708 (doi: 10.1051/apido:2006044).

98. Loucif-Ayad W., Achou M., Legout H., Alburaki M., Garnery L. Genetic assessment of Algerian honeybee populations by microsatellite markers. Apidologie, 2015, 46: 392-402 (doi: 10.1007/s13592-014-0331-0).

99. Alburaki M., Bertrand B., Legout H., Moulin S., Alburaki A., Sheppard W.S., Garnery L. A fifth major genetic group among honeybees revealed in Syria. BMC Genetics, 2013, 14: 117 (doi: 10.1186/1471-2156-14-117).

100. Garnery L., Franck P., Baudry E., Vautrin D., Cornuet J.M., Solignac M. Genetic diversity of the west European honey bee (Apis mellifera mellifera and A. m. iberica). I. Mitochondrial DNA. Genetics Selection Evolution, 1998, 30: S31-S47 (doi: 10.1186/1297-9686-30-S1-S31).

101. Киреева Т.Н., Островерхова Н.В., Конусова О.Л., Кучер А.Н., Шазахов И.В. Морфометрический и молекулярно-генетический анализ медоносных пчел (Apis mellifera L.) на пасеках Томской области. Мат. Межд. конф. «Концептуальные и прикладные аспекты научных исследований и образования в области зоологии беспозвоночных». Томск, 2015: 254-260.

102. Николенко А.Г., Гатауллин А.Р., Каримова А.А. Генетическая структура уральской популяционной системы темной лесной пчелы Apis mellifera mellifera L. Биомика, 2016, 8(2): 82-83.

103. Каскинова М.Д., Ильясов Р.А., Поскряков А.В., Николенко А.Г. Анализ генетической структуры популяций медоносной пчелы (Apis mellifera L.). Генетика, 2015, 51(10): 11991202 (doi: 10.7868/S0016675815100070).

104. Зиновьева Н.А., Кривцов Н.И., Форнара М.С., Гладырь Е.А., Бородачев А.В., Бородачев В.А., Березин А.С., Лебедев В.И. Оценка изменчивости аллелофонда микросателлитов при создании специализированных линий медоносной пчелы среднерусской породы. Достижения науки и техники АПК, 2011, 11: 51-52.

105. Зиновьева Н.А., Кривцов Н.И., Форнара М.С., Гладырь Е.А., Бородачев А.В., Березин А.С., Лебедев В.И. Микросателлиты как инструмент для оценки динамики аллелофонда при создании приокского типа среднерусской породы медоносной пчелы Apis mellifera. Сельскохозяйственная биология, 2011, 46(6): 75-79.

106. Кривцов Н.И., Зиновьева Н.А., Бородачев А.В., Лебедев В.И., Форнара М.С. Дифференциация основных пород пчел с использованием микросателлитов. Вестник ФГБОУ ВПО РГАТУ, 2011, 4(2): 23-27.

107. Зиновьева Н.А., Солошенко В.А., Форнара М.С., Шатохин К.С., Харченко Г.И., Бородачев А.В., Лебедев В.И., Гладырь Е.А., Гончаренко Г.М. Генетическая дифференциация новосибирской популяции дальневосточной пчелы. Доклады РАСХН, 2013, 3: 40-43.

108. Форнара М.С., Крамаренко А.С., Свистунов С.В., Любимов Е.М., Сокольский С.С., Зиновьева Н.А. Морфометрическая и молекулярно-генетическая дифференциация линий и семей медоносной пчелы Apis mellifera caucasica L., разводимых в районе Большого Сочи. Сельскохозяйственная биология, 2015, 50(6): 776-784 (doi: 10.15389/agrobiology.2015.6.776rus).

109. Форнара М.С., Крамаренко А.С., Шаров М.А., Зиновьева Н.А. Исследование аллелофонда и генетической дифференциации дальневосточных пчел. Достижения науки и техники АПК, 2016, 30(10): 101-104.

110. Островерхова Н.В., Конусова О.Л., Кучер А.Н., Киреева Т.Н. Исследование полиандрии у медоносной пчелы (Apis mellifera) с использованием микросателлитных маркеров. Зоологический журнал, 2016, 95(3): 307-313 (doi: 10.7868/S0044513416030119).

\title{
ФГБНУ ФИЦ животноводства -
}

Поступила в редакцию

ВИЖ им. академика Л.К. Эрнста,

21 июля 2020 года

142132 Россия, Московская обл., г.о. Подольск, пос. Дубровицы, 60, e-mail: fomenych@rambler.ru $\bowtie$, margaretfornara@gmail.com,

asnd@mail.ru

Sel'skokhozyaistvennaya biologiya [Agricultural Biology], 2020, V. 55, № 6, pp. 1090-1106

\section{POLYMORPHIC STR MARKERS AS A TOOL FOR POPULATION-GENETIC STUDIES OF Apis mellifera HONEYBEES (review)}

\author{
O.Yu. Fomenko ${ }^{\bowtie}$, M.S. Fornara, A.V. Dotsev
}

Ernst Federal Science Center for Animal Husbandry, 60, pos. Dubrovitsy, Podolsk District, Moscow Province, 142132 Russia, e-mail fomenych@rambler.ru ( $₫$ corresponding author), margaretfornara@gmail.com, asnd@mail.ru ORCID:

Fomenko O.Yu. orcid.org/0000-0001-7852-3790

Fornara M.S. orcid.org/0000-0002-8844-177X

Dotsev A.V. orcid.org/0000-0003-3418-2511 
The relevance of honey bee biology comprehensive study is increasing every year. Primarily, this is caused by the decline of honey bee populations which occurs all over the world including the Russian Federation. Historically, the Europe and Africa continents were the habitat of the only representative of genus Apis, the honey bee Apis mellifera from which a significant number of freely interbreeding races (subspecies) derived during evolution. Nowadays, due to human introduction of honey bees to other continents, Apis mellifera are found all around the world. The loss of unique gene pools and purebred status of native honey bee subspecies due to uncontrolled hybridization is a matter of great concern worldwide (P. de la Rúa et al., 2009). Therefore, evolutionary relationships and population genetics of $A$. mellifera, genetic control of domestic and imported breeding stock purity, breed authentication, genome-wide association mapping for traits of apicultural interest (e.g., queen performance, flight activity, honey and wax productivity, resistance to parasites, winter hardiness, royal jelly components, bee venom, etc.), and breeding value estimation are the key points of approach to biodiversity conservation in honey bees. The set of parameters characteristic of the population/line as a whole is the necessary base to preserve and maintain polymorphism as a component of population stability (N.I. Krivtsov et al., 2011). Genetic structure of breeding populations and relations between geographically isolated populations are relevant to characterize breed gene pool and optimize selection programs. The paper discusses general aspects of microsatellite structure, the main models of evolution (H. Fan et al., 2007) and putative mechanisms of origin in eukaryotic genomes (A.V. Omelchenko, 2013). Microsatellites are tandem repeats of short (2-6 bp) noncoding sequences that are dispersed throughout the nuclear genome (W.S. Sheppard et al., 2000). Microsatellites are located in both protein-coding and non-coding regions, including regulatory sequences (I. López-Flores et al., 2012). It is believed that microsatellites emerge and spread via formation of various non-canonical DNA structures that favor the slipping of replication forks (R.D. Wells, 1996). Microsatellite loci are a very convenient tool to analyze the genetic structure of populations, estimate genomic inbreeding and the level of heterozygosity, calculate genetic similarity coefficients, and determine the level of introgression. This paper overviews the use of STR markers for reconstruction of the honey bee evolutionary history. The principal research papers on population genetics of various $A$. mellifera subspecies from Europe, Asia, America, and Africa are comsidered. Special attention is paid to the Russian honey bee breeds and populations. To summarize, the STR markers due to the large number of alleles, the high frequency of mutational events and codominant type of inheritance continue to be extremely powerful tool for genomic mapping, verification of the genomic authenticity, and in genetic and evolutionary studies of populations.

Keywords: honey bee, microsatellite markers, STR markers, evolution, population genetics, gene pool, introgression. 